\title{
STUDI EKSPERIMENTAL PENGARUH SEKAT PADA TUTUP DAPUR PELEBURAN CRUCIBLE NON FERROUS METAL TERHADAP TEMPERATUR RUANG BAKAR KAPASITAS 3 KG BERBAHAN BAKAR LPG
}

\author{
Chandro H. Butarbutar ${ }^{1 *}$, Mahadi $^{2}$, Indra ${ }^{3}$, Syahrul Abda ${ }^{4}$ \\ ${ }^{1,2,3,4}$ Departemen Teknik Mesin, Fakultas Teknik, Universitas Sumatera Utara \\ candro.butarbutar@gmail.com
}

\begin{abstract}
Abstrak
Industri pengecoran sangat dibutuhkan dalam pengembangan suatu produk,baik permesinan maupun produk rumah tangga.Dapur peleburan logam merupakan suatu alat yang penting dalam menghasilkan suatu produk.Beberapa dapur peleburan telah dikembangkan oleh para peneliti sebelumnya.Dalam penelitian ini dilakukan perancangan dapur peleburan crucible nonferrous metal kapasitas $3 \mathrm{~kg}$ berbahan bakar gas $L P G$ dengan penambahan sekat pada tutup.Tujuan penelitian ini adalah untuk mengetahui pengaruh penambahan sekat pada tutup terhadap kalor yang dibutuhkan untuk meleburkan logam nonferrous metal dan konsumsi bahan bakar yang digunakan.Metode penelitian adalah perancangan ,pembuatan dan pengujian.Pengujian dilakukan dengan cara meleburkan $1 \mathrm{~kg}$ aluminium didapur lebur tanpa dan memakai sekat dengan menggunakan bahan bakar $L P G$ yang dibantu udara dari blower dan dilakukan dilaboratorium Foundry Teknik Mesin USU.Hasil penelitian adalah kalor yang diserap pada dapur peleburan memakai sekat penutup sebesar 20.051,608 kj dengan laju kalor yang terbuang sebesar 3.735,929 $\mathrm{kj} / \mathrm{jam}$ dan banyaknya bahan bakar yang dihabiskan $0,42 \mathrm{~kg}$ dengan waktu peleburan 18 menit.Dan untuk dapur peleburan yang tidak memakai sekat kalor yang diserap sebesar 31.912,738 kj dengan laju kalor yang terbuang sebesar 6.624,29 kj/jam dan banyaknya bahan bakar yang dihabiskan 0,68 kgdengan waktu peleburan 25 menit.
\end{abstract}

Kata kunci : Dapur peleburan, Logam nonferrous ,Bahan bakar $L P G$, Kalor

\section{Pendahuluan}

Pada proses pengecoran, aluminium harus dipanaskan sampai lebur selanjutnya dituang ke dalam cetakan. Proses pemanasan dan peleburan logam dilakukan pada dapur (furnance). Dapur peleburan logam berbagai macam jenisnya baik bentuk maupun jenis bahan bakar yang digunakan[1].

Beberapa dapur peleburan logam berbahan bakar gas LPG telah dikembangkan oleh para peneliti sebelumnya. Sebuah dapur crucible berbahan bakar gas untuk peluburan aluminium scrap telah dirancang dan difabrikasi oleh Esor. Model dapur dirancang sesuai 
untuk kebutuhan laboratorium dan workshop. Hasil uji coba menunjukkan bahwa dapur yang dirancang dapat meleburkan aluminium scrap sebanyak $5 \mathrm{~kg}$ pada temperatur $660^{\circ} \mathrm{C}$ selama 300 detik [2].

Dengan adanya perencanaan pemakaian bahan bakar,dan pemilihan bahan dapur yang tepat serta pemakaian penyekat panas maka efisiensi dan keselamatan kerja dapat ditingkatkan [3].

Penelitian ini merancang sebuah dapur pengecoran logam berbahan bakar gas LPG dengan dilakukan desain pada tutup dapur untuk mempersempit ruang bakar yang bertujuan untuk mengurangi panas yang terbuang pada dapur lebur.

\section{Metode penelitian}

Penelitian dilakuakan di Laboratorium Foundry Teknik Mesin Universitas Sumatera Utara tepat di Jl. Dr. T. Mansur No. 9, Padang Bulan, Medan, Sumatera Utara, Indonesia.

\section{Perencanaan Dapur}

\section{Konstruksi dapur pelebur}

Dapur crucible ini memakai bahan bakar Gas LPG yang memanasi sebuah cawan lebur yang terletak di tengah-tengah sebuah silinder baja yang dilapisi dengan semen tahan api, dimana antara cawan lebur dan semen tahan api tersebut terdapat ruang bakar.

Dapur Pelebur atau Crucible ini dirancang dengan menambahkan sekat penutup pada dapur lebur.Penambahan sekat untuk memperkecil luas ruang bakar.Agar suhu diruang bakar mengalami kenaikan yang cepat,sehingga mempercepat proses peleburan logam nonferrous.Sekat penutup yang dirancang dilapisi dengan semen tahan api.

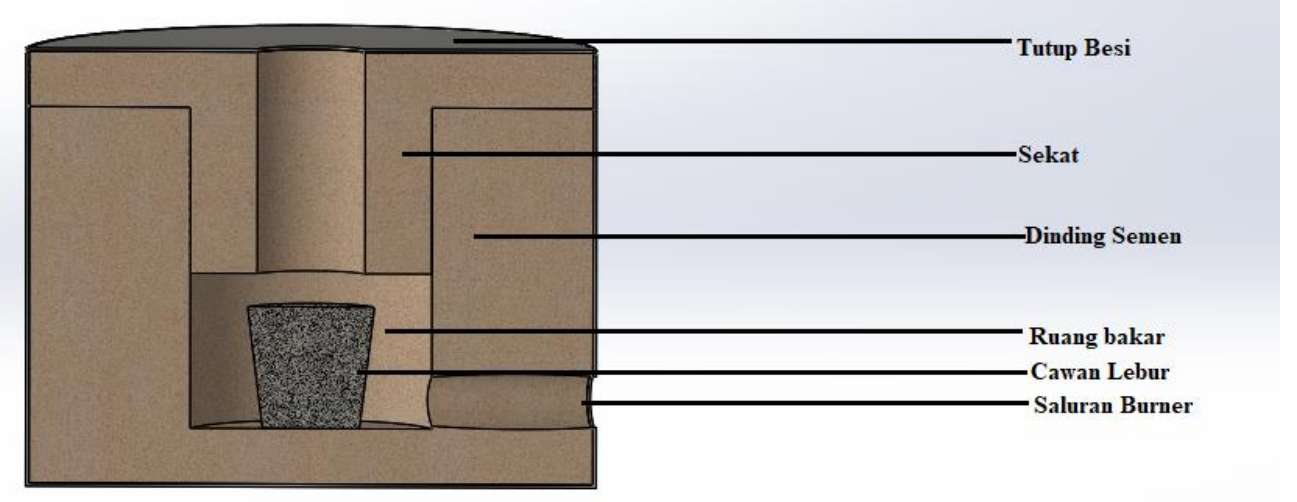

Gambar 2.1 Konstruksi Dapur peleburan

\section{2) Cawan lebur}


Cawan lebur ini mempunyai ukuran-ukuran sebagai berikut :

-Diameter luar : $110 \mathrm{~mm}$

-Tebal : $3 \mathrm{~mm}$

-Tinggi $: 110 \mathrm{~mm}$

Cawan lebur yang dipergunakan adalah silinder baja yang terbuat dari baja paduan yang pembuatannya melalui proses pengolahan panas dengan berbentuk lembaran kandungan karbon rendah. Dapat diketahui temperatur cair dari bahan cawan lebur yaitu baja karbon rendah berkisar $1538^{\circ} \mathrm{C}$ dengan batas temperatur kerja atau sudah mengalami perubahan rekristalisasi pada suhu $810^{\circ} \mathrm{C}$. Sedangkan dapur ini hanya bekerja pada temperatur maksimum $750^{\circ} \mathrm{C}$ dan masih berada di bawah batas temperatur kerja dari baja karbon ini.

\section{Kapasitas Cawan Lebur}

Kapasitas maksimum logam aluminium yang dapat ditampung pada cawan lebur adalah :

$$
\text { wmax }=\text { Vc. } \rho \mathrm{al}
$$

Dimana $: \rho a l=$ berat jenis aluminium $=2707 \mathrm{~kg} / \mathrm{m} 3$

$\mathrm{Vc}=$ volume cawan $=\pi \cdot \mathrm{r}^{2} \cdot \mathrm{t}$

dimana : Dc $=$ diameter alas cawan $=0,11 \mathrm{~m}$

$\mathrm{tc}=$ tinggi cawan maksimum untuk peleburan $=0,11 \mathrm{~m}$

maka : wmax $=\pi \cdot 0,055^{2} \cdot 0,11 \cdot 2700=2,82 \mathrm{~kg}$

kapasitas maksimum dari cawan lebur adalah $2,82 \mathrm{~kg}$

Berat cawan lebur adalah : $\mathrm{W}_{1}=\square . \square . D_{c} \cdot x_{1} \cdot t \square \square / 4 . \square . D_{c}{ }^{2} \cdot x_{1}$

Dimana : $D_{C}=$ diameter luar cawan yaitu $0,11 \mathrm{~m}$

$\square=7801 \mathrm{~kg} / \mathrm{m}^{3}$

$\mathrm{t}=0,11 \mathrm{~m}$

$\mathrm{x}_{1}=0,003 \mathrm{~m}$

maka berat cawan lebur adalah :

$$
W \square \square .7801 .0,11.0,11.0,003 \square \square / 4.7801 .0,11^{2} .0,003
$$

\section{$1,11 \mathrm{~kg} \quad 1$}

\section{3) Ruang Bakar}

Ukuran dari ruang bakar dapur lebur (1) ditentukan dari :

1.Lebar $=2 \cdot 1 / 3$. diameter cawan lebur + diameter cawan +20

$=2 \cdot 1 / 3 \cdot 120+120+20$

$=220 \mathrm{~mm}$ 
2. Tinggi $=$ tinggi cawan lebur +30

$$
=140 \mathrm{~mm}
$$

3. Volume ruang bakar $=$ Volume $\pi \mathrm{d} 2 \mathrm{t}-$ volume cawan lebur

$$
=\pi(0,22) 20,14-\pi(0,11) 20,11=0,017 \mathrm{~m} 3
$$

Ukuran dari ruang bakar dapur lebur (2) ditentukan dari :

1.Lebar $=2 \cdot 1 / 3$. diameter cawan lebur + diameter cawan +20

$$
\begin{aligned}
& =2 \cdot 1 / 3 \cdot 120+120+20 \\
& =220 \mathrm{~mm}
\end{aligned}
$$

2. Tinggi $=$ tinggi cawan lebur $+30+150$

$$
=290 \mathrm{~mm}
$$

3. Volume ruang bakar $=$ Volume $\pi \mathrm{d} 2 \mathrm{t}-$ volume cawan lebur

$$
=\pi(0,22) 20,29-\pi(0,11) 20,11=0,039 \mathrm{~m} 3
$$

\section{4)Semen tahan api}

Semen tahan api yang digunakan adalah semen tahan api $\mathrm{C}_{16}$

$\mathrm{W}_{2}=\left(\pi \mathrm{r}_{\mathrm{a}}^{2} \cdot \mathrm{t}_{\mathrm{a}}-\mathrm{v}_{\mathrm{rb}}\right) \rho_{\mathrm{semen}}+\left(\pi \mathrm{r}_{\mathrm{a}}^{2} \cdot \mathrm{t}_{\mathrm{b}}\right) \rho_{\mathrm{semen}}+\left(\pi \mathrm{r}_{\mathrm{c}}^{2} \cdot \mathrm{t}_{\mathrm{c}}-\pi \mathrm{r}_{\mathrm{b}}^{2} \cdot \mathrm{t}_{\mathrm{c}}\right) \rho_{\mathrm{semen}}$

Dimana :

$\mathrm{W}_{2}=$ berat semen tahan api

$\mathrm{r}_{\mathrm{a}}=$ jari-jari luar semen tahan api $=500 \mathrm{~mm}$

$\mathrm{V}_{\mathrm{rb}}=$ volume ruang bakar $=0,017 \mathrm{~m}^{3}$

$\rho_{\text {semen }}=$ massa jenis semen tahan $\operatorname{api}\left(\mathrm{C}_{16}\right)=2200 \mathrm{~kg} / \mathrm{m}^{3}$

$\mathrm{t}_{\mathrm{a}}=$ tinggi ruang bakar $=140 \mathrm{~mm}$

$\mathrm{t}_{\mathrm{b}}=$ tinggi alas $=56 \mathrm{~mm}$

$\mathrm{t}_{\mathrm{c}}=$ tinggi tutup $=200 \mathrm{~mm}$

$\mathrm{r}_{\mathrm{b}}=$ jari-jari dalam lubang pada tutup $=110 \mathrm{~mm}$

$\mathrm{r}_{\mathrm{c}}=$ jari-jari luar lubang pada tutup $=220 \mathrm{~mm}$

$\mathrm{W}_{2}=\left(\pi \cdot 0,5^{2} \cdot 0.14-0,017\right) 2200+\left(\pi \cdot 0,5^{2} \cdot 0,056\right) 2200+\left(\pi \cdot 0,2^{2} \cdot 0,2-\right.$

$\left.\pi .0 .11^{2} .0,22\right) 2200$

$=337,986 \mathrm{~kg}$

\section{5)Dinding luar}

Dinding luar yang dipakai terbuat dari baja karbon dengan pengerjaan tempa. Ketebalan dinding adalah $3 \mathrm{~mm}$. Plat baja karbon dirol untuk membentuknya menjadi silinder dengan diameter $500 \mathrm{~mm}$. Untuk dinding penahan bagian bawah 
dipasang juga baja ketebalan $3 \mathrm{~mm}$.

Berat dinding luar adalah :

$\mathrm{W}_{3}=$ berat dinding samping + berat dinding atas dan bawah

$$
\mathrm{W}_{3} \square \square . D_{d} \cdot t . x_{d 1} \cdot \square \square 2 . \square / 4 . D_{d}^{2} \cdot x_{d 2} . \square
$$

Dimana :

$\mathrm{D}_{\mathrm{d}}=$ diameter dinding luar yaitu $0,5 \mathrm{~m}$

$\mathrm{t} \quad=$ tinggi dinding $=0,396 \mathrm{~m}$

$\mathrm{x}_{\mathrm{d} 1}=$ tebal dinding samping $=0,003 \mathrm{~m}$

$\mathrm{x}_{\mathrm{d} 2}=$ tebal dinding bawah dan atas $=0,003$

$\rho \quad=$ berat jenis dinding $=7833 \mathrm{~kg} / \mathrm{m}^{3}$

Maka

$\mathrm{W}=\pi \cdot 0,5 \cdot 0,8 \cdot 0,003 \cdot 7833+2 \cdot \pi / 4 \cdot(0,5)^{2} \cdot 0,003 \cdot 7833=47,93 \mathrm{~kg}$

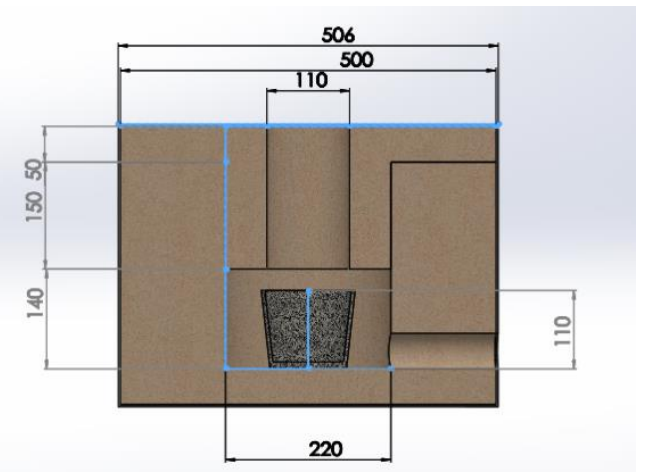

Gambar 2.2. Dimensi dapur lebur yang memakai sekat

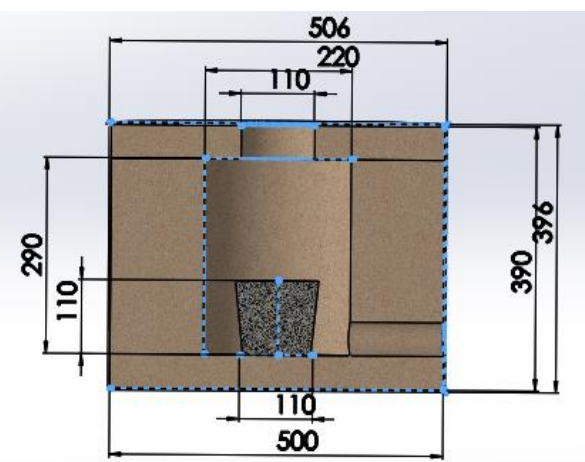

Gambar 2.3 Dimensi dapur lebur tanpa sekat

\section{6)Proses pembuatan dapur lebur}

Proses fabrikasi dapur peleburan dilakukan di Laboratorium Foundry Teknik Mesin Unversitas Sumatera Utara selama kurang lebih 1 bulan. Adapun proses fabrikasi 
terdiri atas : proses pembuatan tutup, proses pembuatan dinding semen, dan proses pemilihan burner.

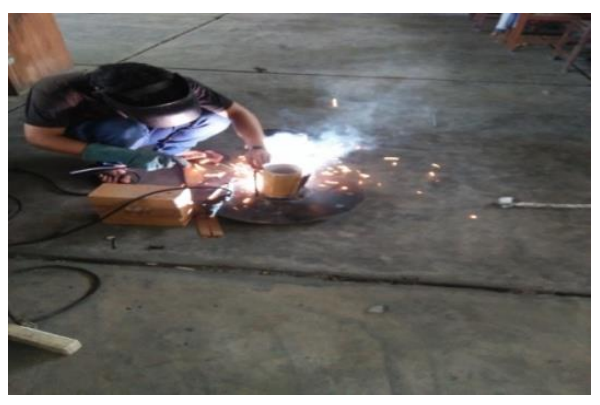

Gambar 2.4 Proses pembuatan tutup

Tutup tungku dibuat dari bahan besi dengan ketebalan $3 \mathrm{~mm}$ dan diameter 500mm. Pada tutup tungku ditambahkan sekat untuk menambah efisiensi dari dapur peleburan. Tutup tungku juga dilapisi semen refractory SCR-16 setebal 50mm. Untuk memperkuat lapisan pada tutup tungku dilas beberapa besi kecil (angker) untuk memperkuat lapisan semen.

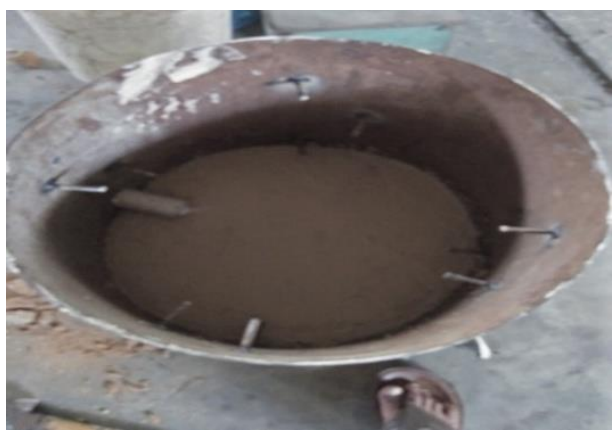

Gambar 2.5Proses pembuatan dinding

Untuk pembuatan dinding tungku, bahan yang digunakan adalah SCR-16 dengan ketebalan 140mm. Sebelum penuangan semen, terlbih dahulu dilas beberapa angker untuk memperkuat dinding semen.

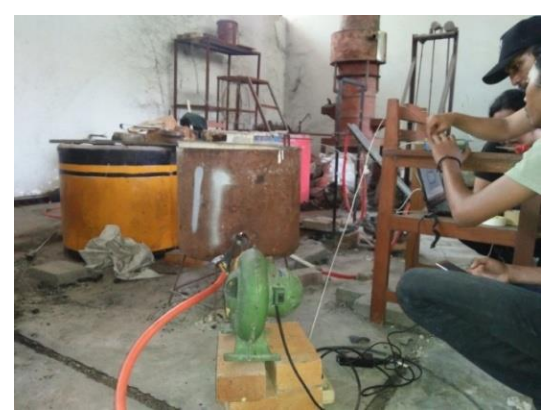

Gambar 2.5 Instalasi burner dan pengujian

Setelah tutup dan dinding selesai kemudian dilakukan pemilihan burner yang sesuai 
dengan tungku. Burner dan blower dimasukkan melalui saluran yang telah disediakan untuk segera dilakukan pengujian temperatur. Hasil pengujian dibaca pada komputer melalui data akuisisi dan kabel termokopel

\section{Hasil dan pembahasan}

\subsection{Hasil pengujian}

Setelah dilakukan pengujian waktu untuk meleburkan $1 \mathrm{~kg}$ aluminium pada dapur 1 atau yang memakai sekat adalah 18 menit.Dan pada dapur 2 atau yang tidak memakai sekat adalah 25 menit.Pengujian dilakukan dengan mengukur suhu Cawan lebur,ruang bakar,dinding dalam, dan dinding luar menggunakan kabel thermokopel.Suhu diukur dari mulai gas dinyalakan sampai aluminium melebur. Berikut data dalam bentuk tabel dan diagram perbandingan pengukuran suhu cawan,ruang bakar,dinding dalam dan dinding luar pada dapur lebur yang memiliki sekat dan yang tidak memiliki sekat.

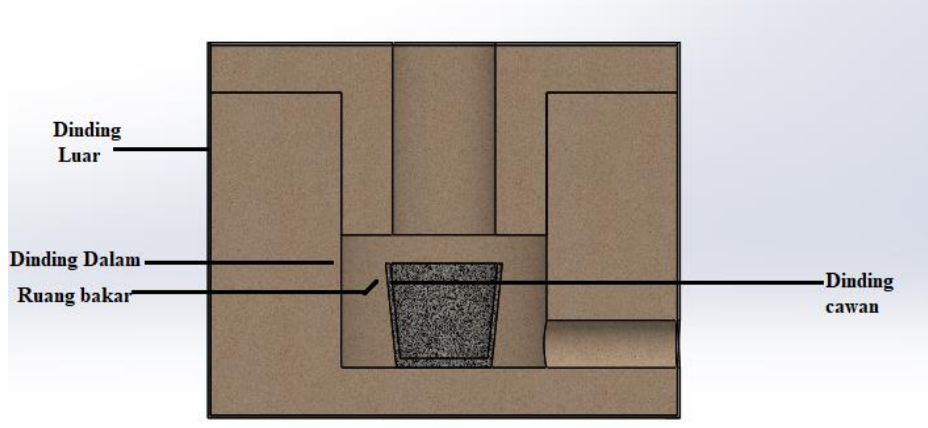

Gambar 3.1 Letak titik pengujian

Tabel 3.1 Suhu pengujian

\begin{tabular}{|c|c|c|}
\hline \multirow{2}{*}{ Letak pengujian } & \multicolumn{2}{|c|}{ Suhu akhir peleburan $\left({ }^{\circ} \mathrm{C}\right)$} \\
\cline { 2 - 3 } & $\begin{array}{c}\text { Dapur lebur yang memakai } \\
\text { sekat }(18 \text { menit })\end{array}$ & $\begin{array}{c}\text { Dapur yang tidak memakai } \\
\text { sekat }(25 \text { menit })\end{array}$ \\
\hline Dinding cawan & 630 & 630 \\
\hline Ruang bakar & 826 & 812 \\
\hline Dinding dalam dapur & 490 & 498 \\
\hline Dinding Luar Dapur & 54 & 53 \\
\hline
\end{tabular}

\subsection{Perhitungan pemakaian bahan bakar}

\section{1)pemakaian bahan bakar dapur yang memakai sekat}

a.) Kalor untuk melebur alumunium (Q1)

$$
\begin{aligned}
& Q_{1}=Q_{A}+Q_{B}+Q_{C} \\
& =m_{a l} \cdot C_{p 1} \cdot \Delta t_{1}+m_{a l} \cdot h+m_{a l} \cdot C p_{2} \cdot \Delta t_{2}
\end{aligned}
$$


Dimana : $m_{a l}=$ Massa aluminium yang akan dilebur $=1 \mathrm{~kg}$

$\mathrm{Cp}_{1}=$ Panas jenis aluminium padat ${ }^{[10]}=0,215 \mathrm{kkal} / \mathrm{kg}^{0} \mathrm{C}$

$\Delta \mathrm{t}_{1}=$ Perbedaan suhu dari titik cair aluminium dengan suhu kamar

$$
=(660-27)^{0} \mathrm{C}=633^{\circ} \mathrm{C}
$$

$\mathrm{h}=$ Panas latent Aluminium ${ }^{[10]}=95 \mathrm{kkal} / \mathrm{kg}$

$\mathrm{Cp}_{2}=$ Panas jenis aluminium cair ${ }^{[10]}$

$$
=0,26 \mathrm{kkal} / \mathrm{kg}^{0} \mathrm{C}
$$

$\Delta \mathrm{t}_{2}=$ Perubahan suhu dari temperatur penuangan ke titik cair $=(750-660){ }^{0} \mathrm{C}=90^{\circ} \mathrm{C}$

Maka kalor untuk melebur Aluminium sebesar : $\mathrm{Q}_{1}=(1 \times 0,215 \times 633)+(1 \times 95)+$ $(1 \times 0,26 \times 90)=254,495 \mathrm{kkal}=1.064,8 \mathrm{kj}$

b) Kalor yang diserap dinding dalam (Q2)

$$
\mathrm{Q}_{2}=\mathrm{m}_{\mathrm{b}} \cdot \mathrm{Cp}_{3} \cdot \mathrm{dt}
$$

\section{Dimana :}

$\mathrm{m}_{\mathrm{b}}=$ Massa dinding dalam yang menerima panas

Berat semen yang menerima panas adalah :

$$
m=1 / 4 \cdot \pi \cdot\left(D 1_{b}{ }^{2}-D_{2 b}{ }^{2}\right) \cdot t_{b} \cdot p
$$

dimana :

$\mathrm{D}_{\mathrm{lb}}=$ diameter luar semen $=0,5 \mathrm{~m}$

$\mathrm{D}_{2 \mathrm{~b}}=$ diameter dalam semen $=0,22 \mathrm{~m}$

$\mathrm{t}_{\mathrm{b}}=$ tinggi semen yang menerima panas

$=0,14 \mathrm{~m}$

$\rho=$ berat jenis semen tahan api $\mathrm{c} 16$

$=2200 \mathrm{~kg} / \mathrm{m}^{3}$

Maka :

$\mathrm{m}=1 / 4 \cdot \pi \cdot\left(0,5^{2}-0,22^{2}\right) \cdot 0,14 \cdot 2200 \quad=48,74 \mathrm{~kg}$

Sehingga didapat:

$\mathrm{m}=48,74 \mathrm{~kg}$

$\mathrm{Cp}_{3}=$ Panas Jenis semen tahan api

$$
=0,23\left(\mathrm{kkal} / \mathrm{kg}^{\circ} \mathrm{C}\right)
$$

Dt $=$ Perubahan suhu di semen tahan api Suhu rata-rata semen tahan api bagian luar adalah $(27+45) / 2=36^{\circ} \mathrm{C}$

Suhu rata-rata semen bagian dalam 
$=490^{\circ} \mathrm{C}$.

Maka suhu rata-rata semen

$$
=(490+36) / 2=263^{\circ} \mathrm{C}
$$

Dengan demikian perubahan suhu (dt)

$$
=263^{\circ} \mathrm{C}-27^{\circ} \mathrm{C}=236^{\circ} \mathrm{C} \text {. }
$$

Sehingga banyak panas yang diserap semen adalah : $\mathrm{Q}_{2}=48,74.0,23.236$

$$
\begin{aligned}
& =2.645,6 \mathrm{kkal} \\
& =11.069,19 \mathrm{kj}
\end{aligned}
$$

c.) Kalor yang Diserap Dinding Plat Luar $\left(\mathrm{Q}_{3}\right)$

Besarnya kalor yang diserap dinding plat luar ini adalah :

$$
\mathrm{Q}_{3}=\mathrm{m}_{\mathrm{p} 1} \cdot \mathrm{Cp}_{4} \cdot \mathrm{dt}
$$

Dimana :

$\mathrm{m}_{\mathrm{p} 1}=$ massa plat luar

$\mathrm{Cp}_{4}=$ panas jenis plat luar ${ }^{[10]}$

$$
=0,46 \mathrm{kkal} / \mathrm{kg}^{0} \mathrm{C}
$$

$\mathrm{dt}=$ perubahan suhu plat

Massa plat yang mengalami perubahan suhu adalah :

$$
m_{p l}=\pi \cdot D_{p} \cdot t_{p} \cdot x_{p} \cdot \rho
$$

Dimana :

$\mathrm{D}_{\mathrm{p}}=$ diameter plat luar $=0,506 \mathrm{~m}$

$t_{\mathrm{p}}=$ tinggi plat yang mengalami perubahan suhu $=0,396 \mathrm{~m}$

$\mathrm{x}_{\mathrm{p}}=$ ketebalan dinding plat $=0,003 \mathrm{~m}$

$\rho=$ berat jenis dinding plat $=7833 / \mathrm{m}^{3}$

Maka :

$$
\begin{aligned}
\mathrm{m} & =\pi \cdot 0,506 \cdot 0,396 \cdot 0,003 \cdot 7833 \\
& =14,78 \mathrm{Kg}
\end{aligned}
$$

Suhu pada plat yang tertinggi adalah $54^{\circ} \mathrm{C}$, dan suhu pada titik $0,396 \mathrm{~m}$ adalah $27^{0} \mathrm{C}$.

Maka suhu rata-rata yang dialami dinding plat ini adalah : $(54+27) / 2=40,5^{\circ} \mathrm{C}$

Maka perubahan suhu $\left(\mathrm{d}_{1}\right)$ yang terjadi adalah $40,5-27=13,5^{\circ} \mathrm{C}$

Maka :

$$
\begin{aligned}
\mathrm{Q}_{3} & =14,78 \mathrm{~kg} \cdot 13,5^{\circ} \mathrm{C} \cdot 0,46 \mathrm{kkal} / \mathrm{kg}^{0} \mathrm{C} \\
& =91,78 \mathrm{kkal}=384,007 \mathrm{kj}
\end{aligned}
$$

d.) Panas yang Diserap Cawan Lebur $\left(\mathrm{Q}_{4}\right)$

Cawan lebur adalah bagian yang paling besar mengalami perubahan suhu. 
Besarnya kalor yang diserap cawan lebur ini adalah :

$$
\mathrm{Q}_{4}=\mathrm{m}_{\mathrm{cl}} \cdot \mathrm{Cp}_{5} \cdot \mathrm{dt}
$$

\section{Dimana :}

$\mathrm{m}_{\mathrm{cl}}=$ massa cawan lebur $=1,11 \mathrm{~kg}$

$\mathrm{Cp}_{5}=$ panas jenis cawan lebur ${ }^{[4]}$

$$
=0,169 \mathrm{kkal} / \mathrm{kg}^{\circ} \mathrm{C}
$$

$\mathrm{dt}=$ perubahan suhu $=\left(\mathrm{t}_{\mathrm{t}}-\mathrm{t}_{0}\right)$

dimana :

$\mathrm{t}_{\mathrm{t}}=$ suhu akhir cawan lebur $=630^{\circ} \mathrm{C}$

$\mathrm{t}_{0}=$ suhu awal cawan lebur $=34^{\circ} \mathrm{C}$

$\mathrm{dt}=630-34=596^{\circ} \mathrm{C}$

Maka :

$\mathrm{Q}_{4}=1,11 \mathrm{~kg} \cdot 0,169 \mathrm{kkal} / \mathrm{kg}^{0} \mathrm{C} \cdot 596^{0} \mathrm{C}$

$$
=111,803 \mathrm{kkal}=467,7 \mathrm{kj}
$$

e.) Panas yang Diserap Plat Atas $\left(\mathrm{Q}_{5}\right)$

Kalor yang diserap plat atas ini dapat dicari dengan rumus :

$$
\mathrm{Q}_{5}=\mathrm{m}_{\mathrm{pl}} \cdot \mathrm{C}_{\mathrm{P} 6} \cdot \mathrm{dt}
$$

Dimana :

$$
\begin{aligned}
\mathrm{m}_{\mathrm{pl}} & =1 / 4 \cdot \pi \cdot\left(\mathrm{D}_{\text {luar }}{ }^{2}-\mathrm{D}_{\text {dalam }}{ }^{2}\right) \cdot \mathrm{t} \cdot \rho \\
& =1 / 4 \cdot 3,14 \cdot\left(0,22^{2}-0,11^{2}\right) \cdot 0,003 \cdot 2200 \\
\mathrm{~m} & =12,53 \mathrm{~kg} \\
\mathrm{C}_{\mathrm{p} 6} & =\text { Panas jenis plat atas }=0,46\left(\mathrm{kkal} / \mathrm{kg}^{\circ} \mathrm{C}\right)
\end{aligned}
$$

Plat akan mengalami perubahan suhu dari $27^{\circ} \mathrm{C}$ sampai ke $320^{\circ} \mathrm{C}$. Maka besarnya perubahan suhu yang terjadi adalah

$$
\mathrm{dt}=320-27=293^{\circ} \mathrm{C}
$$

Dengan demikian :

$$
\begin{gathered}
\begin{array}{c}
\mathrm{Q}_{5}=12,53 \mathrm{~kg} \cdot 0,46 \mathrm{kkal} / \mathrm{kg}^{0} \mathrm{C} \cdot 293^{0} \mathrm{C} \\
\quad=1.688,79 \mathrm{kkal}=7.065,911 \mathrm{kj}
\end{array} \\
\text { Maka kalor total }\left(\mathrm{Q}_{\mathrm{tot}}\right)=20.051,608 \mathrm{kj}
\end{gathered}
$$

Setelah dilakukan perhiungan banyaknya laju aliran kalor yang terbuang dalam proses peleburan ini adalah :

$$
\begin{aligned}
\mathrm{q}_{\mathrm{tot}} & =\mathrm{q}_{1}+\mathrm{q}_{2}+\mathrm{q}_{3} \\
& =(2.052,41+1.330,39+353,129) \mathrm{kJ} / \mathrm{jam} \\
& =3.735,929 \mathrm{kj} / \mathrm{jam}
\end{aligned}
$$


Setelah dilakukan pengujian waktu yang dibutuhkan untuk meleburkan $1 \mathrm{~kg}$ aluminium padat menjadi cair adalah 18 menit.

Dengan demikian didapatnya waktu peleburan maka banyaknya kalor yang terbuang selama proses peleburan dapat diperoleh dengan :

$$
\begin{aligned}
\mathrm{Q}_{\mathrm{t} 2}=\mathrm{q}_{\mathrm{t} . \mathrm{t}} & =3.735,929 \mathrm{~kJ} / \mathrm{jam} \times 0,3 \mathrm{jam} \\
& =1.120,77 \mathrm{~kJ}
\end{aligned}
$$

Bahan bakar yang dipakai dalam proses peleburan ini adalah gas LPG. Bahan bakar ini termasuk bahan bakar gas yang mempunyai nilai pembakaran tinggi (HHV) yaitu $50400 \mathrm{kj} / \mathrm{kg}$.

Maka jumlah bahan bakar yang dibutuhkan adalah perbandingan dari jumlah kalor yang terserap dan jumlah keseluruhan laju aliran kalor dengan jumlah kandungan energi per massa bahan bakar (HHV) yaitu :

$$
\begin{gathered}
\mathrm{m}_{\mathrm{bb}}=\frac{\mathrm{Q}_{\mathrm{t} 1}+\mathrm{Q}_{\mathrm{t}}}{\mathrm{HHV}} \\
\mathrm{m}_{\mathrm{bb}}=\frac{20.051,608 \mathrm{kj}+1.120,77 \mathrm{~kJ}}{50400 \mathrm{~kJ} / \mathrm{kg}} \\
\mathrm{mbb}=0,42 \mathrm{~kg} \quad \text { Maka kebutuhan bahan bakar untuk melebur satu kilogram } \\
\text { aluminium pada dapur lebur yang memakai sekat adalah sebesar } 0,42 \mathrm{~kg}
\end{gathered}
$$

\section{2)Pemakaian bahan bakar dapur tanpa sekat}

Setelah dilakukan pengujian pada dapur lebur tanpa sekat,untuk meleburkan $1 \mathrm{~kg}$ aluminium dibutuhkan waktu 25 menit.

Karena tidak adanya sekat,kalor yang diserap $\left(\mathrm{Q}_{2}{ }^{\prime}\right)$ dan kalor yang terbuang $\left(\mathrm{q}_{1}{ }^{\prime}\right)$ oleh dinding dalam mengalami perubahan.

Perubahan ini terjadi karena bertambahnya dimensi dari tinggi dinding dalam yang menerima panas.Maka :

$$
\mathrm{Q}_{2}{ }^{\prime}=22.930,32 \mathrm{kj}
$$

Dan $\quad . \mathrm{q}_{1}{ }^{\prime}=4.941,11 \mathrm{kj} / \mathrm{jam}$.

Sehingga didapat total kalor yang diserap $\left(\mathrm{Q}_{\mathrm{t} 1}{ }^{\prime}\right)=31.912,738 \mathrm{kj}$ dan $\mathrm{q}_{\mathrm{t}}{ }^{\prime}=$ $6.624,29$.

Dengan demikian banyaknya kalor yang terbuang selama peleburan $\left(\mathrm{Q}_{\mathrm{t} 2}{ }^{\prime}\right)$

$$
\begin{aligned}
\mathrm{Q}_{\mathrm{t} 2}{ }^{\prime} & =6.624,29.25 / 60 \\
& =2.760,12 \mathrm{kj}
\end{aligned}
$$

Maka jumlah bahan bakar yang dibutuhkan untuk meleburkan aluminium $1 \mathrm{~kg}$ pada dapur lebur tanpa sekat ( $\left.\mathrm{m}_{\mathrm{bb}}{ }^{\prime}\right)$ 


$$
\begin{aligned}
\mathrm{m}_{\mathrm{bb}}{ }^{\prime} & =\frac{Q_{\mathrm{t}_{1}}{ }_{\mathrm{HHV}}+\mathrm{Q}_{\mathrm{t} 2}}{\mathrm{HHV}} \\
& =\frac{31.912,738+2.760,12}{50.400} \\
& =0,68 \mathrm{~kg}
\end{aligned}
$$

\section{Kesimpulan}

1. Jenis dapur yang digunakan adalah dapur pelebur jenis krusibel dengan sumber api yang berasal dari GAS LPG

2. Kapasitas peleburan adalah $2,82 \mathrm{~kg}$

3. Cawan lebur

- Tinggi cawan : $110 \mathrm{~mm}$

- Diameter cawan : $110 \mathrm{~mm}$

- Tebal cawan : $3 \mathrm{~mm}$

4. Jenis semen tahan api yang digunakan adalah semen tahan api $\mathrm{C} 16$

5. Pebandingan dapur lebur memakai sekat dan tanpa sekat penutup

\begin{tabular}{|l|c|c|}
\hline & $\begin{array}{l}\text { Dapur lebur memakai } \\
\text { sekat penutup }\end{array}$ & $\begin{array}{l}\text { Dapur Lebur tanpa sekat } \\
\text { penutup }\end{array}$ \\
\hline $\begin{array}{l}\text { Waktu pengujian untuk } \\
\text { meleburkan 1 kg } \\
\text { aluminium }\end{array}$ & 18 menit & 25 menit \\
\hline $\begin{array}{l}\text { Bahan bakar yang } \\
\text { digunakan }\end{array}$ & $0,42 \mathrm{~kg}$ & $0,68 \mathrm{~kg}$ \\
\hline $\begin{array}{l}\text { Jumlah panas yang } \\
\text { diserap }\end{array}$ & $20.051,608 \mathrm{kj}$ & $31.912,738 \mathrm{kj}$ \\
\hline $\begin{array}{l}\text { Jumlah laju aliran panas } \\
\text { yang terbuang }\end{array}$ & $3.735,929 \mathrm{kj} / \mathrm{jam}$ & $6.624,29 \mathrm{kj} / \mathrm{jm}$ \\
\hline
\end{tabular}

\section{Referensi}

[1] Groover, M. P., 2010, Fundamentals of Modern Manufacturing:Materials, Processes, and systems, $4^{\text {the }}$ dition, John Wiley \& Sons,Inc., New York, United States.

[2] Faisal, Muhammad yusuf, Rancang Bangun Dapur Peleburan Logam Nonferrous berbahan bakar Gas Sebagai Sarana Pembelajaran di Laboratorium Teknik Manufaktur,Seminar Nasional Sains dan Teknologi 2016, 2016 
[3] Ginting, Bramanta., 2008, Rancangan Dapur Pelebur Untuk Melebur Aluminium Dan Paduannya Kapasitas 30kg ,USU Repository. 